\title{
A CONSTRUÇÃO DA IDENTIDADE EM CAMPANHA/PEÇA FOTOGRÁFICA DE MODA DE MARCA NACIONAL
}

\author{
The identity building in photographic fashion campaigns/advertisings of national \\ brands
}
La construcción de la identidad en campaña / pieza fotográfica de moda de marca nacional

\section{Resumo}

Josemar Martins

Universidade de Santa Cruz do Sul josem.martins@yahoo.com.br

Elizabeth Bastos Duarte

Universidade Federal de Santa Maria

bebeth@terra.com.br

O presente artigo propõe-se a analisar, na perspectiva de uma semiótica discursiva, a comunicação publicitária direcionada à moda, examinando em especial textos publicitários fotográficos de moda em seu contexto mais amplo, isto é, no interior do veiculo, e relacionados com a campanha de moda da qual fazem parte, com vistas a verificar como eles constroem a identidade e imagem da marca e/ou dos produtos anunciados, bem como quais são as estratégias de que se utilizam para convocar seu público alvo ao consumo e interação com a marca. A análise proposta será realizada em uma peça publicitária pertencente a uma marca de jeanswear que faz parte de campanhas publicitárias fotográficas (outono-inverno), publicada em 2012, pela revista Vogue Brasil, o que, de per si, atualiza a necessidade de examinar, com atenção, para além do publicitário, as características do texto fotográfico e as funções sóciocomunicativas da moda.

Palavras-chave: Publicidade fotográfica. Moda. Mídia revista

\begin{abstract}
This article proposes to examine, since the perspective of a discursive semiotics, advertising communication targeted to fashion, examining in particular photographic fashion advertising texts in their broader context, that is, inside the vehicle, and related to the fashion campaign to which they belong to, in order to check out how they build the identity and image of the brand and / or products advertised, and what are the strategies which are used to summon your target audience to the consumer and interaction with the brand.

The proposed analysis will be conducted through one advertisement belonging to one jeanswear brand that are part of photographic advertising campaigns (autumn-winter), published in 2012, by magazine Vogue Brazil, which, de per si, updates the need to examine carefully, beyond the advertising, the characteristics of the photographic text and the socialcommunicative functions.
\end{abstract}


Key-words: Photographic advertising text. Fashion. Media magazine

\section{Resumen}

En este artículo se pretende analizar, desde la perspectiva de una semiótica discursiva, la comunicación publicitaria dirigida a la moda, examinando en particular los textos publicitarios fotográficos de moda en su contexto más amplio, es decir, en el interior del medio, y en relación con la campaña de moda a la que pertenecen, con el fin de ver cómo construyen la identidad e imagen de marca y / o los productos que se anuncian, y cuáles son las estrategias que se utilizan para llamar a su consumo al público objetivo y la interacción con la marca. El análisis propuesto se llevará a cabo en una pieza publicitaria que pertenece a una marca de ropa vaquera que forma parte de las campañas de publicidad fotográficas (otoño-invierno), publicado en 2012 por la revista Vogue Brasil que, en sí mismo, actualiza la necesidad de examinar, con cuidado, además de la publicidad, las características del texto fotográficas y funciones socio-comunicativas de la moda.

Palabras clave: Publicidad fotográfica. Moda. Medios de revistas

\section{CONSIDERAÇÕES INTRODUTÓRIAS}

Quando se observa a mais singela peça de uma campanha fotográfica de moda, verificase de pronto que o mundo por ela ofertado ao espectador é estrategicamente construído; trata-se de um mundo-mercadoria, prenhe de valores que objetivam seduzir/tentar o público-alvo ao consumo.

Lembra-se a esse respeito que fotografias de moda veiculadas em revistas não só, na maioria das vezes, fazem parte, de uma campanha, como se relacionam com outras estruturas e peças publicitárias que constituem o seu entorno, que é a revista. Há, assim, estruturas concorrentes, de certa forma, semelhantes, homogêneas, nas quais essas publicidades se apóiam, que reiteram os sentidos por ela veiculados, mas dificultam sua distinção, visto que fazem parte de sua textualidade.

Assim, o objetivo geral deste trabalho é examinar como, frente a aparente recorrência e reiteração de imagens, atua discursivamente uma empresa pertencente ao mercado de moda contemporâneo, através da veiculação em revista, de peça fotográfica de sua campanha publicitária de moda, para conferir identidade e imagem a seus produtos/marcas, com vistas a interpelar seus virtuais consumidores; de que estratégias discursivas se utiliza para persuadi-los a consumir os produtos/marcas anunciados; como impõe ideias ou conceitos ligados a esses produtos/marcas; como relaciona seu consumo com uma dada representação identitária do receptor. 


\section{SENTIDOS DA MODA E CONFORMAÇÃO CORPORAL}

Ao longo do séc. XX, com o desenvolvimento do mercado da moda, o ideal estético de corpo, principalmente o feminino, foi-se modificando em consonância com a moda. Segundo Duarte e Fensterseifer (2007), a moda interfere na conformação corporal, não deixando dúvidas de que o corpo é concebido como um texto em que se projetam diferentes sentidos e que esses sentidos são sonhados pela indústria da moda, da cosmética, do corpo. A consideração do corpo como manifestação direta do que se é, sugere a observação de diferentes comportamentos - postura, respiração, peso, movimentos, gestos, expressões faciais, entonação de voz, vestuário, adornos -, ligadas a leituras de caráter cultural e social. Assim, se a natureza é força primitiva, rude, turbulenta -, a beleza, o charme, o glamour, a elegância ofertados por esse mercado são as armas de que se dispõe para controlá-la, para domesticá-la.

Com a globalização e a midiatização, a estética e a moda passaram a definir a imagem corporal a ser perseguida. Através dela, a sociedade passou a selecionar, controlar, dispor e impor sobre a própria produção dos seus corpos. A indústria da moda, como a da cosmética e a da beleza, tornaram-se ferramentas preciosas para esse controle corporal, que, aliás, se submete ao que, do ponto de vista econômico, interessa aos mercados. Nesse processo de imposição, um dos argumentos mais definitivos é a estética das manequins, geralmente magras e jovens, cuja imagem vincula-se a poder, status e elegância, tornando-se um padrão de comportamento e estética a ser seguido.

Em estreita relação com uma temporalidade da vida cotidiana, com uma pragmática do corpo e uma gramática das normas sociais, a moda é uma construção simbólica muito particular, que relaciona simultaneamente diferentes ordens de significação social. Diante de tudo que vem sendo discutido, fica evidente que a moda constitui-se como um verdadeiro dispositivo semiótico.

Assim, os seres humanos, atendendo ou não aos apelos da moda, perderam a inocência: portar uma vestimenta é fundamentalmente um ato de produção de sentidos, que ultrapassa, em muito, razões como o pudor, a proteção ou o mero adorno. $\mathrm{E}$ toda a produção de sentidos está ligada ao social.

Segundo Canclini, o consumo é um "conjunto de processos socioculturais em que se realizam apropriação e os usos dos produtos” (1999, p. 77). Ligada à ideia de organização social, o consumo de bens materiais ou simbólicos confere às pessoas identidade e, 
simultaneamente, pertencimento a um grupo. Nessa perspectiva, os sujeitos passam a ser definidos pelo que consomem.

Sim, porque o consumo de determinado produto relaciona os consumidores com certos valores, identificando-os e integrando-os em grupos específicos. Nesse processo, a interferência das mídias é essencial, visto que provoca uma unificação fundada na partilha de códigos de identificação: mesmo quem nunca saiu de seu país, se identifica com marcas, pessoas e objetos de outras culturas.

Além de uma função utilitária, outras lógicas presidem o consumo da moda, fundamentadas em uma racionalidade de caráter sociopolítico, em que o consumo se refere à participação em um cenário de disputas por aquilo que a sociedade produz e pelos modos de usá-lo; em uma racionalidade de caráter simbólico ou estético, em que o consumo se funda em signos de status; e em uma racionalidade de caráter interativo, em que o consumo confere signos de pertencimento ou participação em um determinado grupo social. Um dos sentidos agregados à moda advém dos valores conferidos ao próprio consumo da moda.

A moda vincula-se, a um novo modo de agir da sociedade: as pessoas são o que são, via aquilo que consomem. $\mathrm{O}$ ato de consumir determinado produto estabelece valores, identifica pessoas e as integra em grupos específicos: o comportamento de aceitação ou contestação do consumidor em relação ao conjunto de valores representado por uma tendência de moda justifica-se pela necessidade de apropriação de bens materiais e simbólicos, definidores de uma cidadania que se materializa via participação em determinado grupo.

\section{AÇÃO PUBLICITÁRIA E CAMPANHAS PUBLICITÁRIAS DE MODA}

A ação publicitária corresponde a um tipo particular de processo comunicativo que tem por objetivo central a promoção de empresas, marcas, produtos e/ou serviços, com vistas à aquisição e consumo por parte dos virtuais consumidores. Esse tipo de processo comunicativo comporta um entorno cultural, social, situacional; sujeito(s) emissor(es)/produtor(es), a empresa anunciante e os realizadores da campanha ou texto publicitário; dirige-se a um público definido - seus prováveis consumidores; e utiliza-se de um veículo/plataforma como suporte para sua veiculação.

Enquanto mensagem desse processo comunicativo, a publicidade está vinculada a uma formação discursiva que determina seus poderes e regra suas formas de manipulação. Nessa perspectiva, embora a publicidade possa, e o faz, explicitar, sem subterfúgios, sua intenção 
objetiva e interesseira - o fazer comprar/usar - ela, simultaneamente, recorre a diferentes formas de convencimento e utiliza-se de diversas estratégias para construir a identidade do que anuncia com vistas a poder interpelar os consumidores.

Em contrapartida, como todos sabem de seus poderes, os consumidores, a seu turno, desenvolvem imunidades contra seus efeitos interpelatórios: mais do que reconhecer suas intenções, descaracterizam suas estratégias, redimensionam suas hipérboles, desacreditam suas metáforas.

A publicidade contemporânea normalmente recorre, em suas narrativas, à atualização original de certos mitos na pretensão de alcançar formas criativas de interpelação dos virtuais consumidores: o inédito como forma de despertar o interesse e fixar a marca ou produto na memória do consumidor. Em nome disso, novos anúncios, novos visuais, novos fatos. Mas, ao convocar esses temas como formas de manipulação, substituindo o aspecto interesseiro pelo espetáculo de um mundo onde comprar é reencontrar a origem - do prazer, do bem-estar, da harmonia -, as publicidades não o podem fazer sem sobre eles se posicionarem. Ora, é por isso que toda a manipulação - sedução, tentação, provocação, intimidação - assenta-se sobre um sistema de valores: o mesmo sistema de valores que governa a produção desse tipo de formação discursiva, controlando os limites e as formas do dizível; em princípio, esses valores são os convocados a dar sustentação aos processos manipulatórios.

\section{FUNDAMENTOS TEÓRICO-METODOLÓGICOS: A SEMIÓTICA DISCURSIVA}

Para Greimas, a semiótica tem por objetivo a exploração dos sentidos, não se restringindo à descrição da comunicação, mas buscando dar conta de um processo mais amplo que é o da significação, muitas vezes, para além do mero ato de comunicar.

O objeto de estudo da semiótica é o texto, independentemente das linguagens de que ele se utiliza para sua expressão, fixando-se na análise da narratividade, compreendida como a instância geradora da significação, pressuposta por qualquer manifestação discursiva e determinadora de suas condições de colocação em discurso.

O esquema narrativo pode ser trabalhado em dois patamares de profundidade desigual, o semionarrativo (estrutura fundamental e narrativa) e o discursivo, cada um deles possuindo sua gramática própria, cujos componentes são a sintaxe e a semântica.

O percurso de análise proposto por Greimas parte do exame da estrutura mais simples e abstrata em direção às formas mais complexas e concretas, ou seja, da estrutura fundamental, à 
narrativa e à discursiva. A instância fundamental, primeira etapa do percurso, é o espaço no qual a significação se manifesta de forma mais abstrata, como uma oposição semântica mínima. A instância narrativa é responsável pela organização da narrativa do ponto de vista de um sujeito: os valores presentes nas oposições semânticas fundamentais, assumem aqui a forma de ações que relacionam os diferentes sujeitos, fazendo circular esses valores. A instância discursiva é o espaço em que as oposições fundamentais, assumidas como valores narrativos, desenvolvem-se sob a forma de temas, materializados em investimentos figurativos, convocando procedimentos de ordem sintática, tais como actorialização; temporalização; espacialização; tonalização.

Assim, enquanto as estruturas narrativas podem ser consideradas como pertinentes ao imaginário humano, as configurações discursivas submetem-se a filtragens de ordem semiocultural.

O nível de análise privilegiado pelo presente estudo é o discursivo, espaço de manifestação das escolhas operadas pelo sujeito da enunciação quanto ao modo de contar a narrativa. Nesse nível, são os componentes semânticos e sintáticos que possibilitam as seleções e combinações a serem realizadas pelo enunciador.

A colocação em discurso das estruturas semióticas profundas e narrativas se dá através de procedimentos de tematização e figurativização. A sintaxe discursiva comporta pelo menos quatro componentes: actorialização, temporalização, espacialização e tonalização. Tais componentes visam à produção de um dispositivo de atores, de um quadro espaço-temporal, de um arranjo tonal, no qual são inscritos os programas provenientes da instância superior.

A enunciação é o espaço de geração do discurso, responsável por um duplo processo de seleção. De um lado, o enunciador seleciona as estruturas semionarrativas de que tem necessidade; de outro, realiza as escolhas, no interior das possibilidades oferecidas pelo sistema, da combinatória de unidades discursivas em condições de produzir os efeitos de sentido pretendidos, operando os arranjos das unidades que lhe convêm.

O tipo de relação contraída entre texto e enunciação é de ordem metonímica, sendo a enunciação o todo, e o texto a parte. O nível da enunciação acompanha a totalidade do discurso; nessa perspectiva, o discurso comporta três níveis: o da enunciação, o do enunciado e o da enunciação enunciada.

Examinando o modelo greimasiano, fica evidente que o autor parte do pressuposto de que toda a ação é fruto de manipulação, que se sustenta em um sistema de valores de caráter ideológico. Greimas identifica quatro grandes figuras de manipulação; a sedução, que opera via

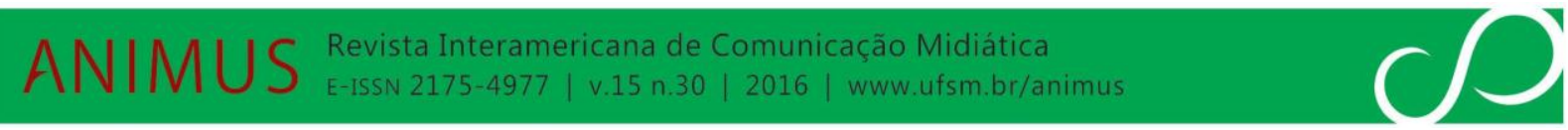


encantamento; a tentação, que opera via aliciamento, suborno; a intimidação, que opera pelo temor, pelo medo; e a provocação, que opera pelo desafio, pela incitação.

Segundo Greimas, nenhum processo comunicativo é inocente; há sempre uma intenção, o que o subordina ao princípio da eficácia. Cada um dos participantes do jogo comunicativo visa a com-vencer o outro, isto é, não só vencer como obriga-lo a partilhar de sua vitória. Como o que importa é o êxito, podem ser utilizadas diferentes formas de persuasão, quer as de ordem argumentativa, que se regem pela razão; quer as de ordem manipulatória, envolvendo um querer ou um dever fazer.

A manipulação tem, assim, por meta um fazer fazer. Para tanto, segundo Althusser (1985), transforma indivíduos concretos em sujeitos, para poder dotá-los de desejos e deveres, o que os torna passíveis de interpelação. Daí por que manipular requer a partilha de um mesmo sistema de valores.

\section{METODOLOGIA DE ANÁLISE}

O objetivo geral do presente artigo é examinar, como, frente a tanta recorrência e reiteração, atuam discursivamente as diferentes empresas pertencentes ao mercado de moda contemporâneo, através de campanhas publicitárias fotográficas de moda, veiculadas por revistas, para conferir identidade e imagem a seus produtos/marcas, com vistas a interpelar seus virtuais consumidores; de que estratégias discursivas se utilizam para persuadi-los a consumir os produtos/marcas anunciados; como impõem ideias ou conceitos ligados a esses produtos/marcas; como relacionam seu consumo com uma dada representação identitária do receptor.

A partir do objetivo geral, além da recuperação das transformações por que passou o mercado da moda no decorrer do século $\mathrm{XX}$, e do exame das alterações vivenciadas pelas revistas de moda mais atuantes no decorrer dos últimos 50 anos, estabeleceram-se como objetivos específicos: (1) analisar a campanha publicitária fotográfica, da qual faz parte a peça publicitária selecionada para compor o corpus do trabalho; (2) descrever a peça publicitária selecionada, examinando: (a) as estratégias empregadas na construção da imagem e marca de sua grife; (b) os procedimentos discursivos adotados na construção da identidade do consumidor - configuração sexual, etária, nacionalidade, pertencimento de classe ou grupo social -, com vistas à sua interpelação e manipulação; (3) examinar as ideias, conceitos e 
valores agregados, bem como as configurações temporais e tonais atribuídas às marcas/produtos nas campanhas publicitárias selecionadas.

\section{ANÁLISE DA PEÇA PUBLICITÁRIA}

\section{1 Âmbito comunicativo/enunciativo}

A análise a seguir apresentada compreende o exame: do entorno comunicativo/enunciativo das peças publicitárias selecionadas, envolvendo o suporte midiático onde foram veiculadas, a revista Vogue, as marcas anunciantes e a instância de realização das campanhas; da relação entre a peça publicitária selecionada e outras do mesmo gênero que aparecem na revista Vogue, de onde foram retiradas; da relação entre a peça publicitária e outras produzidas pela mesma campanha; da peça publicitária do ponto de vista de sua estruturação interna. Como alguns dos elementos desse entorno comunicativo são comuns a todas as peças publicitárias fotográficas em análise, optou-se por apresentar primeiramente a caracterização da revista que lhes serve de plataforma midiática.

\subsection{Mídia veiculadora: Vogue Brasil}

A Vogue atualmente é a revista feminina de moda mais importante, conceituada e influente do mundo. Publicada pela Condé Nast Publications em 19 países (Alemanha, Austrália, China, Espanha, França, Itália, Rússia, Japão, Coréia do Sul, Grécia, México, Reino

Unido, Taiwan, Brasil, Estados Unidos, Portugal, Índia, Turquia e Holanda, além de ser vendida em mais de 90 outros países), veicula mensalmente trabalhos de estilistas, escritores, fotógrafos e designers, apresentados na perspectiva sofisticada do mundo da moda, da beleza e da cultura pop. A publicação tem uma circulação mensal mundial estimada em três milhões de exemplares.

Em um movimento circular, a revista destaca os profissionais ligados ao mundo da moda, as modelos, os fotógrafos, os estilistas e produtores e até mesmo os próprios jornalistas. Mas, a Vogue hoje ultrapassa as tendências atuais de moda, pois vê nelas conceito, atitude, arte e status; contextualiza a moda, anuncia as tendências, resgata influências e história. Uma outra característica da publicação é a ênfase por ela conferida aos novos estilistas, nos quais aposta, antevendo êxitos futuros. Além disso, a revista apresenta ousados e inovadores ensaios fotográficos e editoriais de moda, bem como atores sociais, em sua maioria, participantes do 
mundo da moda, da alta sociedade e celebridades. Os produtos e grifes anunciados, cujos preços são exorbitantes, acabam por atribuir status à revista e aos consumidores.

\subsection{Marca anunciante}

A Ellus nasceu em 1972, em São Paulo, pelas mãos de Nelson Alvarenga que trouxe o jeans para o Brasil em uma época em que ele não era usado como atualmente. Alvarenga criou a marca com o intuito de oferecer aos jovens da época o mesmo ideal que se vivia na década de 70 nos EUA: a luta pela liberdade de expressão. O jeans era visto, então, como ícone de rebeldia.

Atualmente, a Ellus está entre as marcas líderes no mercado de jeans, sendo reconhecida pelos traços de personalidade forte, de caráter autêntico e ousado, o que mantém seu nome sempre em alta. Além de vender e revender seus produtos via website, a marca pode ser encontrada em lojas espalhadas por todo o Brasil e em países como Angola, EUA, Emirados Árabes, Japão, Suiça e Chile. Denominada anteriormente Ellus do Brasil Confecções e Comércio Ltda., em agosto de 2008, passou a sociedade anônima, com denominação Ellus do Brasil Confecções e Comércio S.A., operando com as marcas Ellus e 2nd Floor, com 30 lojas próprias e 34 franqueadas, localizadas em 25 municípios do Brasil.

A Ellus participa do calendário oficial da moda brasileira, a São Paulo Fashion Week, na qual apresenta coleções de calças jeans e camisetas com aspectos de sujas, empoeiradas ou rasgadas, muitas peças em couro, xadrez e cortes militares, tudo sempre com uma temática ligada à cultura jovem.

Os preços utilizados pela Ellus para a venda de seus produtos não podem ser considerados populares: uma calça jeans pode custar de meio salário mínimo até mil reais, destinando-se prioritariamente a um público de médio a alto poder aquisitivo.

\section{Dados de identificação}

Empresa anunciante: Ellus do Brasil Confecções e Comércio S.A.

Marca anunciada: Ellus

Equipe publicitária responsável: Profissionais de moda: Adriana Bozon (diretora geral), Kleber Matheus (diretor de arte), Jacques Dequeker (fotógrafo), Rodrigo Pollack (produtor de moda), Robert Estevão (maquiador e cabeleireiro), Aline Weber (modelo), Alicia Kuczman (modelo), Baptiste Demay (modelo), Marlon Teixeira (modelo) e Leandro Lima (modelo).

Local do anúncio: Revista Vogue Brasil 
Data de publicação: ed. 406 - jun. 2012.

Título da campanha: Ellus Jeans Deluxe outono-inverno 2011/2012

\subsection{Mediação enunciativa: equipe publicitária e fotógrafo}

A campanha publicitária Ellus Jeans Deluxe outono-inverno 2011/2012 foi produzida por um grupo de profissionais de moda que atuam de forma autônoma, do qual fazem parte os profissionais já identificados nos dados de identificação, o que deixa claro o investimento feito pela marca em sua produção.

O fotógrafo responsável foi Jacques Dequeker, natural de Porto Alegre - RS (1970), que vive em São Paulo desde 1998. Autodidata, começou a fotografar em 1997, influenciado por amigos como o fotógrafo Pedro Flores e o maquiador Duda Molinos, cujo trabalho inspira muitas das imagens por ele realizadas. Em 2000, Dequeker publicou seu primeiro ensaio na revista Vogue Brasil, com a qual, desde então, tem colaborado regularmente. Em 2002, ganhou o prêmio da Associação Brasileira da Indústria Têxtil como melhor fotógrafo de moda do Brasil. No ano seguinte, em 2003, começou a publicar suas fotos na Europa. Vogue Portugal, a edição francesa de Marie Claire, Glamour Paris, a sueca Forum Hasselblad, V Magazine, TWILL, o jornal El Pais, entre outros, são alguns dos títulos nos quais o fotógrafo tem trabalhos publicados.

\subsection{Modelos alocados}

Para a campanha publicitária Ellus Jeans Deluxe outono-inverno 2011/2012, foram convocados cinco modelos: Aline Weber, Leandro Lima, Marlon Teixeira, Alicia Kuczman e Baptiste Demay. Trata-se de modelos que gozam de prestígio nacional e internacional: todos são famosos e apresentaram trabalhos para marcas conhecidas, além de alguns pertencerem ao ranking de modelos mais importantes e bem pagos do mundo.

\subsection{Caracterização geral da campanha publicitária fotográfica Ellus Jeans Deluxe Outono/Inverno 2011/2012}

A peça em análise faz parte da campanha publicitária fotográfica denominada Ellus Jeans Deluxe Outono/inverno 2011/2012, fotografada por Jacques Dequeker, em um casarão, no bairro Bela Vista, em São Paulo, é composta por dezoito fotografias e apresentada por cinco modelos, duas mulheres e três homens (Aline Weber, Alicia Kuczman, Baptiste Demay, 
Leandro Lima e Marlon Teixeira). Somente a peça em análise foi publicada na revista Vogue Brasil (ed. 406, jun. 2012, p. 18 e 19).

Nove das fotografias estão em posição horizontal e nove, em vertical, dividindo-se para apresentar seis imagens com todos os modelos; duas apenas com uma modelo feminina; cinco com casais de modelos; quatro com o modelo inteiro e a metade de outro modelo (as pernas); e duas com uma modelo feminina e a metade de outra.

Sob direção geral de Adriana Bozon, que é também diretora de estilo da Ellus, as peças da campanha propõem um tom simultaneamente despojado, sexy e fetichista, com muitas roupas pretas, em couro; muitas fendas, decotes, transparências, tachas e silhuetas muito próximas ao corpo, detalhes que reiteram o tom da coleção. A modelo Aline Weber, que, pela segunda vez estrela uma campanha da Ellus, aparece em destaque na maioria das fotografias. As características da campanha reforçam um cenário geral que aponta para o rock n' roll, um dos principais traços de identidade da marca; os materiais metalizados e o couro com textura, conferem toques pesados a esse cenário.

Como já se referiu, o tom geral que perpassa a campanha fotográfica é de erotismo, sensualidade, expresso pelas poses insinuantes dos modelos, juntos ou isolados, pelos corpos esculturais à mostra, alguns deles seminus, exibindo os homens de cuecas e as mulheres com roupas que se assemelham a lingeries.

Embora algumas das imagens apresentem os modelos em movimento, a maioria exibe manequins estáticos, dando-se a ver, oferecendo-se, insinuando-se para o espectador/leitor, para o virtual consumidor. Em duas fotografias, em ambiente externo, aparece um carro, no qual os modelos estão recostados. Em outras imagens, há poltronas e um sofá de couro, no qual os modelos aparecem deitados, sentados ou recostados.

Em 17 fotografias aparece a frase Ellus Jeans Deluxe; em apenas uma delas o slogan não vem inscrito. As fotos exibem, na maioria das vezes, as mulheres em primeiro plano e os homens, em segundo, como meros coadjuvantes. O foco das imagens enfatiza pernas e pés, tal como aquela em que aparece um homem pisado pelas pernas de uma mulher, indicando a submissão do masculino.

A relação da peça publicitária em análise com as demais da mesma campanha é de semelhança e complementaridade, pois faz parte de um sentido construído pela sequência das imagens, que, no entanto, recorrem a diferentes estratégias discursivas para manifestá-lo. Analisando isoladamente cada uma das peças, perde-se, por exemplo, o sentido de traços como 
solidão, isolamento, inocência, recato, incomunicabilidade que figuram ao lado do erotismo e sensualidade que dominam a campanha.

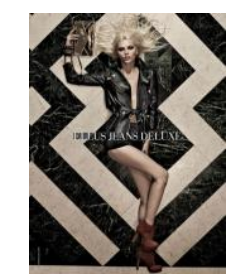

Figura 28

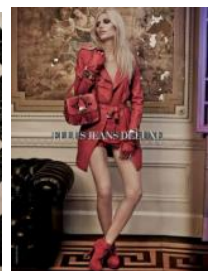

Figura 29

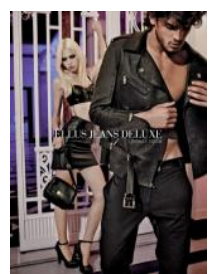

Figura 30

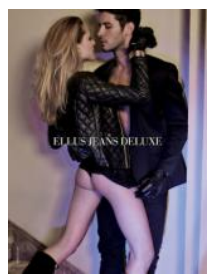

Figura 31

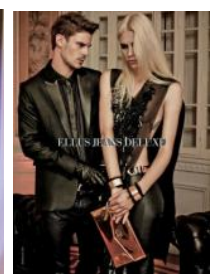

Figura 32

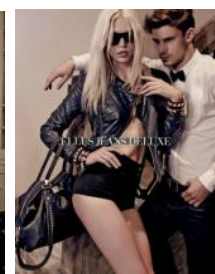

Figura 33

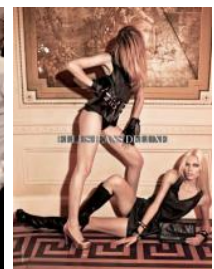

Figura 34
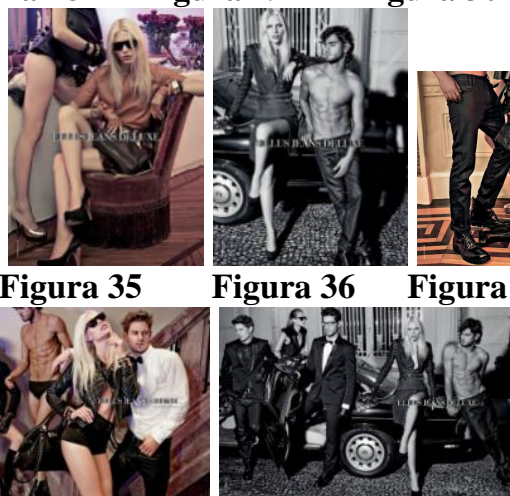

Figura 41
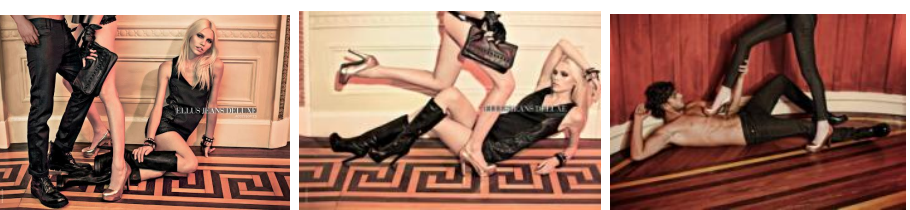

Figura 38

Figura 39

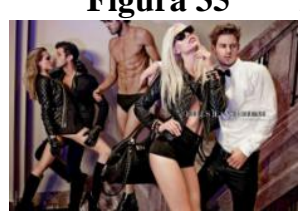

Figura 40

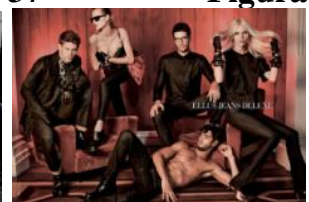

Figura 43

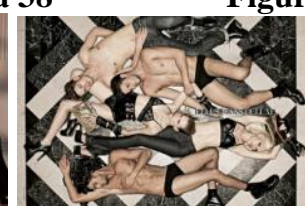

Figura 44

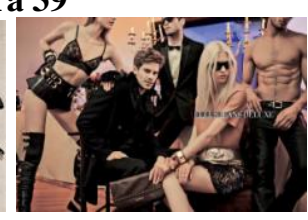

Figura 45

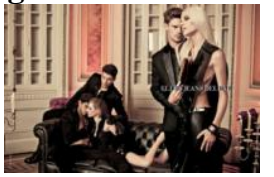

Figura 46

\subsection{Relação da peça com outras publicadas na revista}

A relação entre a peça publicitária em exame e outras do mesmo gênero, que, publicadas na ed. 406 - jun. 2012, na revista Vogue Brasil, é, por vezes, de semelhança, e, por outras, de diferença. Muitas delas anunciam perfumes, relógios, óculos, bolsas, roupas que apresentam semelhanças estéticas com os produtos da Ellus.

Há neste número da revista Vogue, com 283 p., um total de 69 peças publicitárias. Dentre elas, a da Ellus é a de n. 09, ilustrando as p. 18 e 19, precedida pela oferta de produtos das seguintes marcas: Natura (cosméticos), Chanel (bolsa), Dolce \& Gabbana (óculos de sol), Sephora (cosméticos), Victor Hugo (bolsas), Calvin Klein Jeans (jeans), Top Shot (roupas) e Diesel (jeans). Pode-se dizer que a peça está não só em boa companhia, como entre as de maior destaque na revista, visto que ocupa espaço entre grifes mundialmente conhecidas.

Dentre o total de peças publicitárias exibidas neste número da Vogue, outras sete marcas também divulgam jeanswear - quatro internacionais e três nacionais -, motivo pelo qual nelas se concentra a atenção. Essas peças pertencem respectivamente às grifes Calvin Klein 
Jeans, Diesel, 7 for all mankind, Colcci, Carlos Miele Jeans, M.Officer e Carmim; todas elas se dirigem ao público jovem.

As peças publicitárias que aparecem antes da Ellus são: a da Calvin Klein Jeans (p.12 e 13), que apresenta duas mulheres sensuais na praia; a da Diesel (p. 16 e 17), que mostra uma mulher no colo de um robô, segurando uma rosa branca, em cenário construído.

As peças que aparecem depois da Ellus são: a da 7 for all mankind (p. 50), que exibe uma mulher em destaque e um casal em foto menor; a da Colcci (p.83), que mostra apenas uma mulher seminua, deitada sobre um gliter dourado (a peça faz parte do corpus de pesquisa); a da Carlos Miele Jeans (p. 89 e 91), que apresenta uma mulher aparentemente em uma fazenda; a da M.Officer (p. 111 e 113), que exibe um casal em clima de namoro; e a da Carmim (contracapa interina), que mostra um casal em clima de amoro, em fundo infinito.

As sete primeiras peças, estão antes da metade da revista (p. 142), sendo que apenas a publicidade da Carmim aparece no final da publicação (p. 283), na contracapa interina, o que se configura como espaço nobre na publicação. É importante ressaltar que, na revista, há um anúncio de empresa têxtil especializada em jeans, a Covolan, além de uma matéria, de seis páginas, intitulada Último grito, que faz referência às tendências da moda jeans.

Analisando o perfil do público alvo projetado pelas marcas anunciantes, pode-se dizer que o virtual consumidor dessas peças são jovens abastados, acostumados ao conforto, qualidade e prazer.

\subsection{Descrição da publicidade em análise}

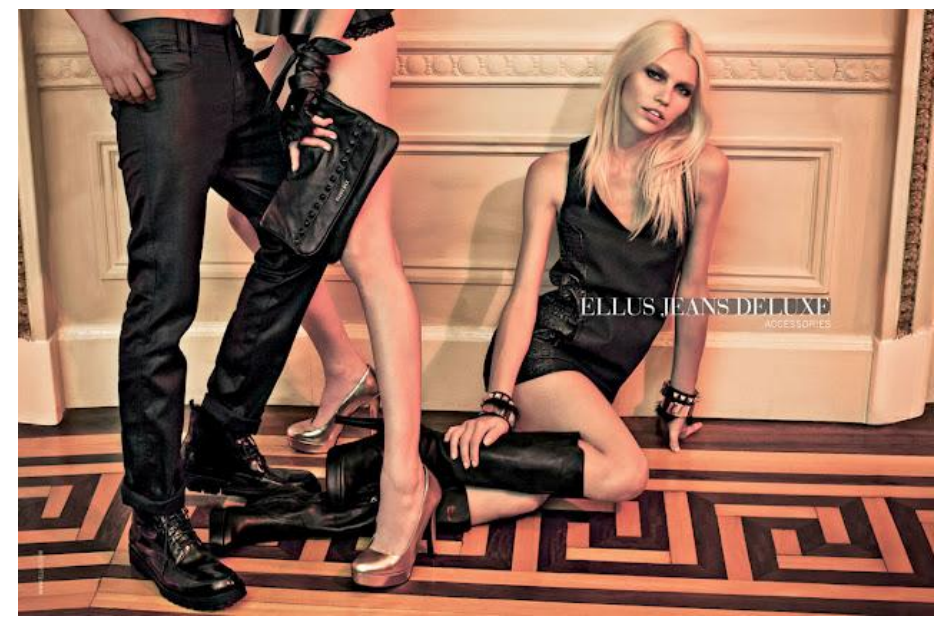

Figura 47 
A peça publicitária da campanha Ellus Jeans Deluxe outono-inverno 2011/2012, publicada na ed. 406 - jun. 2012, da revista Vogue Brasil, p. 18 e 19, é uma fotografia horizontal, que apresenta a modelo loira Aline Weber, sentada no chão, sobre um trilho senegalês de ráfia, olhar distante, alienado, recostada em uma parede com detalhes em Art déco, em tom bege. Aline usa um vestido preto com detalhes em couro, bota na mesma cor e material, e pulseiras em estilo punk rock, com ilhoses. A pose da modelo é bastante insinuante: pernas de fora, dobradas, cabeça inclinada à direita, rosto com maquiagem pesada, quem lembra o estilo heroin chic, de modelos drogadas dos anos 90. Além disso, sua aparência é semelhante a da atriz e modelo francesa Brigitte Bardot. À esquerda de Aline, aparece a metade de duas outras pessoas, possivelmente um homem e uma mulher. O homem usa uma calça com a barra dobrada e botas também de couro preto; a mulher veste uma lingerie preta e segura uma bolsa de couro com a inscrição Ellus $D L X$, usa luvas em couro preto e sapato em cor metalizada.

$\mathrm{Na}$ foto, como um todo, predominam cores quentes: o bege, o preto e suaves reflexos avermelhados. Em se tratando dos aspectos cromáticos, a tonalidade da fotografia oscila entre cores quentes e neutras, apresentando médios-contrastes, o que nesse caso, indica a emissão de uma fonte de luz única. Possivelmente, a fotografia foi iluminada com um flash, o que gera um médio contraste, com sombras suaves, reforçando a intenção da peça publicitária. Outra característica importante é a tomada de câmera, que neste caso é frontal, colocando o observador em igualdade com o motivo retratado na peça publicitária.

O traço de enfaro que perpassa a peça, contrasta com o apelo erótico que ela contém; afinal, trata-se de uma mulher sensual e insinuante, de pernas de fora, com roupas marcadas pelo fetichismo. A narrativa destaca a mulher; é ela quem protagoniza indicando o poder do feminino sore o masculino. Tanto isso é verdade que, no par que também é representado na imagem, não é dado a ver os rostos. No entanto, a presença de ambos, demonstra preocupação da Ellus, enquanto marca de jeanswear, de construir uma imagem unissex. A frase Ellus Jeans Deluxe Acessories está presente, superposta à fotografia, em destaque, à direita da imagem, complementando a narrativa como símbolo de luxo e sofisticação.

Pode-se dizer que há uma diferença entre os valores ofertados e as formas de dizer da peça publicitária em análise. Mesmo sendo veiculada pela Vogue, revista de moda com público-alvo bem definido, a peça publicitária da Ellus assemelha-se tecnicamente a outras veiculadas na mesma edição, diferenciando-se, no entanto, pela escolha e emprego de algumas estratégias discursivas. A configuração de imagem é a de um público que tem tudo, que não se 
choca e nem se preocupa com nada, são jovens alheios, entediados e envoltos em diversão, luxo e prazeres.

\subsection{Temática central}

A peça publicitária em análise tem como temática central o alheamento do contexto, o distanciamento e ausência de deslumbramento em relação ao ambiente de luxo, beleza e erotismo que circunda a protagonista principal, comportamento que é reforçado pelo slogan Ellus Jeans Deluxe Acessories, pelas roupas pretas e sofisticadas, acessórios exibidos, e pela pose aparentemente despretensiosa da modelo. A temática estrutura-se a partir da oposição entre valores de dominação vs submissão; feminilidade vs masculinidade; possibilidade vs impossibilidade; indiferença vs interesse; distanciamento vs proximidade; satisfação vs insatisfação; ousadia vs recato; modernidade vs tradição.

\subsection{Estratégias de manipulação}

Com o intuito de interpelar e convocar o público-alvo da marca ao consumo, a peça publicitária fotográfica se utiliza simultaneamente de figuras de manipulação de quatro ordens: sedução, tentação, intimidação, provocação. Ao mesmo tempo em que seduz, porque encanta pela beleza que dá a ver ao espectador, tenta pelos traços de erotismo e sensualidade que deixa antever; intimida pela inversão de poder aqui centrado no feminino; provoca e desafia pela indiferença e desinteresse em relação ao contexto e ao espectador. A fotografia sugere, pelos valores que, simultaneamente, coloca em jogo, a independência do feminino conquistada também pela utilização das diferentes peças da Ellus e dos sentidos a elas atribuídos.

\subsection{Configurações discursivas: identidade e projeção da imagem do produto e do consumidor}

Por meio das escolhas discursivas empregadas na construção de sua narrativa, a peça publicitária fotográfica em análise projeta simultaneamente a imagem de marca/produto anunciada e do público-consumidor que visa a interpelar. Com isso, convoca os sujeitos a se identificarem com a marca/empresa anunciante e com os produtos por ela ofertados ao mercado. Esse processo de projeção/introjeção de imagem/marca se utiliza de dispositivos discursivos distintos, manifestos pela seleção de diferentes estratégias discursivas.

Configuração do público consumidor: a configuração do cenário onde se passa a narrativa e dos protagonistas da peça publicitária, figuras masculinas e femininas da peça publicitária, é 
marcada pelo requinte, beleza e charme. A referência a esses traços, projeta a imagem do público a que a peça visa interpelar: trata-se de jovens habituados à beleza, ao status, ao prazer e ao sexo, que, consequentemente não se deslumbram, permanecem indiferentes. $\mathrm{O}$ virtual consumidor representado no interior da própria foto é tanto aquele jovem acostumado a conviver com esses valores, como aqueles que buscam esses valores. Existe um movimento circular de projeção e reflexão da imagem em que ao observador são conferidos os mesmos valores que portam e constituem os jovens, objeto da narrativa.

Caracterização dos atores da narrativa: o protagonista principal da narrativa é uma mulher, a modelo Aline Weber, com visual dos anos 60 (Brigitte Bardot), uma vez que os outros dois atores são vistos apenas da cintura para baixo. Trata-se de uma jovem loura de extrema beleza, corpo escultural, ar blasè, olhar um tanto esgazeado, indiferente ao que se passa, sentada de forma bastante sensual. Os traços de beleza que a configuram - juventude, altura, magreza, proporcionalidade, brancura e clareza - reforçam o padrão estético europeu, decorrente de uma hegemonia de caráter histórico, cultural e econômico. Assim, a escolha de uma modelo loira, ao invés de uma morena ou negra, não é inocente: ela conforma, de certa forma, os requintados consumidores alvo da marca. Os outros dois atores, um homem e uma mulher que aparecem apenas da cintura para baixo no texto fotográfico, embora sejam meros coadjuvantes, reforçam esse padrão estético predominante: são brancos, com corpos perfeitos, em pose amorosa, sensual, erótica.

Caracterização do espaço/cenário: o espaço em que se desenvolve a ação da narrativa é o ambiente interno de uma mansão, da qual só alguns detalhes podem ser visualizados; eles apontam, não obstante, para uma residência requintada: a parede que aparece como fundo da fotografia contém detalhes que remetem a art déco e o piso é recoberto por um trilho senegalês de ráfia bastante em voga. Não se trata de um cenário que possa ser facilmente identificado com vistas a se estabelecerem vínculos históricos ou culturais definidos. Essa indefinição do espaço, não obstante, não impede a identificação do requinte e sofisticação do ambiente por todos aqueles que têm acesso ou almejam esses traços de berço, tradição, luxo e riqueza, direcionando a marca a um determinado perfil de consumidor.

Marcas temporais expressas: a configuração temporal, um tanto vaga, acontece a partir de elementos presentes na peça publicitária fotográfica, em especial, no que concerne às roupas e à caracterização dos atores, pois não existem referências temporais definidas, até mesmo porque a cena acontece em uma casa com características de requinte e tradição. As pulseiras estilo punk rock, as roupas em couro, as poses dos modelos que poderiam parecer contraditórias com 
o ambiente, remetem a uma época de efervescência do movimento punk, logo, a um passado relativamente próximo, reforçando os traços de tradição e qualidade atribuídos aos produtos de moda anunciados.

Combinatória tonal conferida: o tom conferido à peça publicitária fotográfica alia erotismo e sensualidade a uma certa irreverência, indiferença, descaso e enfaro, capazes de desestabilizar o status quo. Trata-se de um tom passível de interpelar os jovens que podem pagar o preço da marca. A imagem oferta erotismo e juventude, mas, para chegar a isso, é preciso consumir os produtos oferecidos. Os acessórios do rock reforçam a imagem de um público jovem e moderno, vinculando a marca à juventude, rebeldia, contestação e tradição, que a marca Ellus se atribui enquanto identidade.

\section{APONTAMENTOS FINAIS}

O presente artigo propôs-se a verificar como os textos publicitários fotográficos, veiculados em revista impressa de moda nacional, constroem a imagem da marca e/ou dos produtos que anunciam e de seus virtuais consumidores; de que estratégias se utilizam para interpelar seu público alvo ao consumo. Considerando este objetivo central, analisou-se uma peça publicitária fotográfica, publicada na revista Vogue Brasil, durante o ano de 2012, em suas campanhas outono/inverno, com vistas a melhor compreender o duplo movimento por ela empreendido na persuasão dos virtuais consumidores. Cabe lembrar que, embora as marcas/produtos examinados sejam de jeanswear, trata-se de peças de grife, cujo custo de aquisição é bastante alto.

A análise realizada possibilitou o reconhecimento dos traços identitários empregados pela empresa na configuração de sua imagem/marca e de seu público alvo, fornecendo uma caracterização muito clara dos sujeitos envolvidos nesse processo comunicativo publicitário. Em grande parte da peça publicitária examinada, há uma recorrência explícita a traços de juventude, requinte, classe, sofisticação, sensualidade e erotismo, combinados com altivez, autossuficiência, enfaro na configuração identitária dos protagonistas dessas narrativas.

Fica evidente que as agências publicitárias e fotógrafos de moda vêm utilizando, na composição dos textos fotográficos publicitários, determinados elementos sempre reiterados. Parece não haver espaço para o novo, para formulações criativas que dêem visibilidade a novos fotógrafos, e, mais ainda, que permitam identificar e diferenciar marcas. 
O fato de os fotógrafos responsáveis por essas campanhas, no Brasil e no exterior, serem sempre os mesmos, possivelmente seja responsável por uma sensação de mesmice que perpassa todas essas publicidades fotográficas de jeanswear. Mais ainda, essa reiteração de formas de expressão e conteúdo nas campanhas publicitárias de moda estende-se também aos formatos adotados e modelos contratados que repetem o mesmo padrão de beleza, as mesmas poses, bocas e trejeitos, os mesmos apelos sexuais, entre outros. Além disso, em todos os casos, os modelos convocados são profissionais que gozam de fama e reconhecimento internacional, o que agrega prestígio e qualidade à identidade das marcas e, de certa forma, transfere esses valores aos virtuais consumidores.

O perfil do consumidor da marca de jeanswear traçado por essa publicidade é o de jovens bonitos, sarados, bem sucedidos, requintados, acostumados ao luxo, à sofisticação, a ambientes privativos e exclusivos - aqueles com condições financeiras para portar a marca. Aliás, o fato de as peças publicitárias serem veiculadas pela Vogue já é indício de que se trata de um público classe média alta, convocado a um consumo que é sinônimo de prazer, distinção e status.

A ênfase, no texto publicitário analisado, recai sobre a figura feminina, cabendo ao homem, o papel de mero coadjuvante, o que se deve possivelmente ao fato de as mulheres conferirem maior valor ao mundo da moda e das marcas, além de o público da revista Vogue ser predominantemente feminino.

A narrativa da peça publicitária analisada se constrói a partir de uma ideia ou conceito partilhado, que fala de uma geração de jovens abonados, que vivem em meio ao luxo, ao conforto e às regalias de um mundo globalizado: são jovens belos, magros, sarados, sensuais, mas que parecem ter perdido o tesão, a ambição, o desejo, enfarados que estão com tantas facilidades e benesses.

A análise da peça publicitária da Ellus demonstra que a marca permanece arraigada a um estilo mais juvenil e despojado, que, aliás circunscreve suas campanhas publicitárias como um todo. Essa reiteração, como já se referiu, diz respeito, tanto ao estilo das peças de vestuário como aos formatos adotados pelas publicidades, que se utilizam das mesmas estratégias discursivas e mecanismos de expressão. Possivelmente isso seja decorrência do fato de o universo de produção e realização dessas campanhas ser bastante restrito, convocando sempre as mesmas equipes e fotógrafos para pensar e produzir essas publicidades de moda. Cria-se, com isso, um estilo comum que perpassa toda a produção publicitária fotográfica de moda, banalizando as publicidades e, de certa forma, não distinguindo entre si as marcas anunciantes. 
Ao que tudo indica, a intenção de todas as marcas de jeanswear - que surgiu caracterizando primeiramente os cowboys americanos e, posteriormente, a juventude hippie - é transformar, pelo uso que faz dele, esse tipo de vestuário em peça requintada e de grife, a ser usada em todas as situações sociais, fugindo completamente de seus sentidos iniciais: de utilitária e despojada, passaram à ícone de riqueza e distinção.

Cabe notar que o erotismo e a sensualidade que impregna a maior parte da publicidade muitas vezes vêm acompanhados de traços de tédio e enfaro, empregados na configuração dos protagonistas dessas narrativas publicitárias. Essa reiteração serve, de certa forma, para reforçar a imagem de todas essas grifes caras, que assim se reforçam e acabam por legitimar umas as outras. É como se dissessem: compre de qualquer um de nossos produtos, desde que façam parte desse círculo restrito de grifes, que interagem entre si e reforçam o status de quem as utiliza.

Perpassam as peças publicitárias analisadas um despudor coletivo em relação ao corpo; um erotismo aliado ao ócio; um hedonismo descompromissado de afetos; e, mais que tudo, uma altivez, quase soberba, uma autoconfiança ilimitada, e mesmo um enfaro, um tédio, como se tudo já tivesse sido visto, experimentado, usado, sendo próprio e privativo daqueles que têm tudo, dos que não precisam desejar. Será que é essa inapetência que busca a classe emergente? Isto porque é, sem dúvida, com esses traços que configura a identidade dos jovens belos, ricos e famosos da pós-modernidade, que dispõem de um mundo prazeroso e sofisticado, e de grana para a aquisição desse tipo de mercadoria.

O alheamento, a inapetência, marca registrada dessas peças publicitárias, desperta atenção, pois emprega como estratégia persuasiva para o fazer comprar o nada desejar. Interpela-se, assim, um público alvo emergente ao uso do jeanswear a altos preços, oferecendo como imagem a ser perseguida aqueles que nada mais têm a ambicionar, porque já possuem, já têm tudo. Será que é isso que desejam aqueles que ainda desejam? Nada a desejar? Mesmo o tom de irreverência, rebeldia e contestação, mais visível nas peças publicitárias da Ellus, perde sua força: o jeans há muito deixou de representar esses traços.

Curiosamente, esse setor que não apresenta muitas inovações na forma de anunciar seus produtos, que reitera as estratégias de oferta empregadas há bastante tempo, tem a cada ano aumentado seu mercado de consumidores. Se o jeans vem sendo usado há muitos anos por todas as classes sociais, se o tecido é o mesmo, produzido e distribuído no Brasil por uma única empresa, a Santista, que entrega as peças de vestuário, inclusive, já cortadas; se a distinção 
entre as peças jeanswear se dá por meros detalhes de acabamento - o que lhes confere identidade é a marca e o preço.

Não fica difícil, dessa forma, compreender o motivo pelo qual as publicidades, veiculadas, a altos custos na revista Vogue Brasil, empreguem estratégias tão semelhantes, que liquidem com qualquer possibilidade de distinção entre as diferentes grifes: elas, assim, acabam, em conjunto, por se configurarem, todas, por traços de exclusividade, luxo, poder e sucesso. A recorrência do consumidor a essas marcas só pode se explicar por essa fetichização que se faz de uma classe social, transformada em objeto de desejo: é a ascensão a ela que explica o deslumbre que todas essas grifes provocam nos consumidores.

\section{REFERÊNCIAS BIBLIOGRÁFICAS}

ALI, Fátima. A arte de editar revistas. São Paulo: Companhia Editora Naciona=, 2009.

ALTHUSSER, Louis. Aparelhos ideológicos de estado. Rio de Janeiro: Graal, 1985.

BARROS, Diana Luz Pessoa de. Teoria semiótica do texto. 4. ed. São Paulo: Ática, 2003.

BAUDRILLARD, Jean. O sistema dos objetos. São Paulo: Perspectiva, 1973.

BERTRAND, Denis. Caminhos da semiótica literária. Bauru, SP: EDUSC, 2003.

BLUMER, Herbert. Suggestions for the study of mass-media effects. In: Symbolic

Interactionism: perspective and method. New Jersey: Prentice Hall, 1969

BOURDIEU, Pierre. A economia das trocas simbólicas. (Introdução, organização e seleção de Sérgio Miceli). São Paulo: Perspectiva, 1974.

O poder simbólico. 9 ed. Rio de Janeiro: Bertrand Brasil, 2006.

. A distinção: crítica social do julgamento. Trad. Daniela Kern; Guilherme J. F.

Teixeira. São Paulo: Edusp, 2008.

BRAGA, João. Reflexões sobre moda. Volume I / João Braga com colaboração de Mônica Nunes. 2. ed. rev. São Paulo. Anhembi Morumbi, 2005.

CANCLINI, Néstor Garcia. Consumidores e cidadãos: conflitos multiculturais da globalização. 4 ed. Rio de Janeiro: UFRJ, 1999.

CASTRO, Maria Lília Dias de. Discurso publicitário: o encontro de vozes. In: VI Congresso Internacional de Ciências da Comunicação dos Países de Língua Portuguesa da Federação Lusófona de Ciências da Comunicação. Anais... LUSOCOM, Covilhã, 2004. 
Movimento promocional: falar de si para poder falar dos outros. In: XVIII Encontro Nacional da Compós. Anais... Belo Horizonte, 2009.

Pro-movere: o discurso para o mercado. In: XXXIV Intercom, Congresso Brasileiro de Ciências da Comunicação. Anais... Recife, 2011.

CESAR, Nilton; PIOVAN, Marco. Making Of: revelações sobre o dia a dia da fotografia. 1 ed. São Paulo: Futura, 2003.

CHIMINAZZO, Ricardo. Tendências e novos formatos das peças publicitárias. In: PEREZ, Clotilde;

BARBOSA, Ivan Santos (Org). Hiperpublicidade: atividades e tendências. Vol. 2. São Paulo: Thomson Learning, 2008.

CIDREIRA, Renata Pitombo. Os sentidos da moda. São Paulo: Annablumme, 2005.

CODATO, Henrique; LOPES, Flor Marlene E. Semiologia e semiótica como ferramentas metodológicas. In: DUARTE, Jorge; BARROS, Antonio (ogs). Métodos e técnicas de pesquisa em comunicação. São Paulo: Atlas, 2005, p. 206-214.

DEQUEKER, Jacques. Entrevista Nunca estou 100\% satisfeito. Separata de: Revista Photos \& Imagens. Balneário Camboriú: Editora Photos, ed. 76, p.11 a 15, mai/jun. 2010.

DUARTE, Elizabeth Bastos. Fotos \& grafias. São Leopoldo: Unisinos, 2000.

Televisão: ensaios metodológicos. Porto Alegre: Sulina, 2004.

DUARTE, Elizabeth Bastos; FENSTERSEIFER, Carlos Ramiro Padilha. Dos sentidos da moda. In: Colóquio da moda. Anais do Colóquio da moda (eletrônico). Porto Alegre: IPA, 2007.

ECO, Umberto. Apocalípticos e integrados. 4ª ed., São Paulo: Perspectiva, 1990.

2004.

História da beleza / Umberto Eco; tradução Eliana Aguiar. Rio de Janeiro: Record,

FERREIRA, Aurélio Buarque de Holanda. Novo dicionário da língua portuguesa. Rio de Janeiro: Nova Fronteira, 1975.

FLOCH, Jean-Marie. Semiotique, marketing ET communication - Sous lês signes les strategies. Paris: Presses Universitaries de France, 2003.

FLÜGEL, J. C. A psicologia das roupas. São Paulo: Mestre Jou, 1966.

FONTANILLE, Jacques. Tensão e significação/Jacques Fontanille, Claude Zilberberg; Trad. Ivã Carlos Lopes, Luiz Tatit e Waldir Beividas. São Paulo: Discurso/ Humanitas/FFLCH/USP, 2001.

FOUCAULT, Michel. A ordem do discurso. São Paulo: Loyola, 1996. 
FRANÇA, José Carlos. Tendências e novos formatos das peças publicitárias. In: PEREZ, Clotilde; BARBOSA, Ivan Santos (Org). Hiperpublicidade: atividades e tendências. Vol. 2. São Paulo: Thomson Learning, 2008.

GREIMAS, Algirdas Julien. Introdução à semiótica narrativa e discursiva. Tradução Norma Backes Tasca. São Paulo: Coimbra, 1970.

Difel, 1976.

Semiótica do discurso científico. Da modalidade. Trad. Cidmar T.Pais. São Paulo:

GREIMAS, Algirdas Julien. COURTES, Joseph; tradução Alceu Dias Lima... [et al.].

Dicionário de semiótica. São Paulo: Cultrix, 1979.

. Semântica estrutural. São Paulo: Cultrix, 1973.

HALL, Stuart. A identidade cultural na pós-modernidade. Rio de Janeiro. DPCA, 2006.

HEDGECOE, J. O novo manual de fotografia: [guia completo para todos os formatos]. 2. ed. São Paulo: Senac, 2005.

JOFFILY, Ruth. Jornalismo e a Produção de Moda. Rio de Janeiro, Nova Fronteira, 1991.

LOVATT-SMITH, Lisa. 100 Anos de Moda. Vogue Brasil 259, São Paulo, editora Carta, 1999.

MARRA, Claudio. Nas sombras de um sonho: histórias e linguagens da fotografia de moda. São Paulo: Senac, 2008.

MARTÍN-BARBERO, J. Dos meios às mediações: comunicação, cultura e hegemonia. 5. ed. Rio de Janeiro: UFRJ, 2008.

SARLO, Beatriz. Cenas da vida pós-moderna: intelectuais, arte e videocultura na Argentina. Trad. Sérgio Alcides. 2. ed. Rio de Janeiro: UFRJ, 2000.

SOULAGES, François. Estética da fotografia: perda e permanência. Trad. De rai D. Poletti e Regina Salgado Campos. São Paulo: SENAC, 2010.

SUSS, Liana; ZABOT, Tatiana. Análise completa das revistas do segmento de moda Vogue Brasil e Elle. Anais do XXXII Congresso Brasileiro de Ciências da Comunicação Intercom. Curitiba, 2009. 
Aperfeiçoamento de Pessoal de Nível Superior (CAPES). Bacharel em Comunicação Social, habilitação em Jornalismo pela Universidade de Cruz Alta /RS (2005). Foi integrante do grupo de pesquisa COMTV, focado na análise da comunicação televisual e nos processos de produção de significação e sentidos dos textos televisuais -, sob coordenação das profas. Dra. Elizabeth Bastos Duarte e Dra. Maria

Lilia Dias de Castro. Atuou em áreas do jornalismo impresso, jornalismo digital e assessoria de imprensa. Áreas de interesse: análise do discurso, semiótica discursiva, publicidade e fotografia. Atualmente é professor do curso de Comunicação Social/Produção em Mídia Audiovisual e Subcoordenador do curso Superior de Tecnologia em Fotografia da Universidade de Santa Cruz do Sul/UNISC.

Elisabeth Barros Duarte

Graduada em Letras pela Universidade Federal do Rio Grande do Sul (1968), mestre em Letras pela Universidade Federal do Rio Grande do Sul (1982) e doutora em Lingüística e Semiótica pela Universidade de

São Paulo (1989). Pós-doutora em Televisão pela École des Hautes Études en Sciences Sociales (França) e pela Université de Paris III Sorbonne Nouvelle (França). Pesquisadora IC do CNPq, Professora adjunta IV (aposentada) UFRGS. Professora titular II da Universidade do Vale do Rio dos Sinos (1995-2007). Professora permanente do PPGCom da Universidade Federal de Santa Maria - UFSM (2007atual). Experiência na área de Comunicação, com ênfase nos estudos midiáticos, em especial, Televisão, atuando na intersecção entre semiótica e teorias da comunicação.

Esta obra está licenciada sob uma Licença Creative Commons. 